\title{
Representasi Indonesia pada penanganan COVID-19 di media asing
}

\author{
Susanne Dida ${ }^{1}$, Trie Damayanti ${ }^{2}$, Aang Koswara ${ }^{3}$ \\ 1,2,3 Universitas Padjadjaran, Bandung, Indonesia
}

\begin{abstract}
ABSTRAK
Corona Virus Disease 19 (COVID-19) merupakan sebuah krisis global yang menimpa hampir semua negara di dunia. Seperti halnya sebuah krisis, diperlukan strategi dalam menanganinya, dan strategi itu harus dilakukan secara cepat dan tepat. Efektivitas pemilihan sebuah strategi akan teruji pada hasil akhir dimana jika krisis ini sedang berlangsung dan di akhir krisis. Para ahli krisis mengatakan bahwa pada dasarnya krisis terbagi menjadi tiga tahap yaitu, pre-crisis, crisis, dan postcrisis, dan COVID-19 ini sedang dalam tahap krisis. Strategi komunikasi yang dipilih dalam penanganan krisis ini sudah sepantasnya harus menggunakan kehatihatian karena COVID-19 ini merupakan pertaruhan semua Negara untuk menunjukkan kapasitas negaranya sehingga reputasi negara tersebut tetap terjaga dengan baik di mata negara lain. Sorotan media di seluruh dunia, pada seluruh negara yang terkena dampak COVID-19 ini menjadi acuan bagaimana reputasi negara tersebut, dan bagaimana kemampuan negara tersebut berkompetisi dengan negara lain dalam menghadapi COVID-19. Penelitian ini dengan menggunakan metode penelitian deskriptif yang melibatkan pengembangan kerangka pengkodean dan pengkodean kualitatif terhadap media-media pada April hingga Mei 2020 ini bertujuan melihat bagaimana Indonesia di mata media asing, sehingga akan terlihat bagaimana reputasi Indonesia di mata dunia. Identitas dan persepsi orang luar negara Indonesia menjadi tolak ukur yang akan dilihat dari representasi Indonesia melalui tulisan-tulisan yang ada di media massa asing. Hasil penelitian menunjukkan bahwa image dan reputasi Indonesia yang kurang baik, yang diawali dengan kelemahan public statement yang dilakukan pemerintah Indonesia, yang berefek pada persepsi yang kurang baik terbentuk dari pemberitaan di bulan-bulan selanjutnya.
\end{abstract}

Kata-kata Kunci: Representasi Indonesia; krisis; penanganan COVID-19; reputasi; media asing

\section{Indonesia's representation on handling COVID-19 in foreign media}

\begin{abstract}
Corona Virus Disease 19 (COVID-19) is a global crisis that affects almost all countries in the world. Like any other crisis, a strategy is needed to handle it, and that strategy must be carried out in a rapid and precise way. The strategy selection's effectiveness will be determined at the final results, whether on the ongoing crisis or at the end of the crisis. A crisis is divided into three stages: pre-crisis, crisis, and post-crisis; the current COVID-19 situation is at a crisis stage. The carefully made decision in communication strategy handling of the COVID-19 crisis brings about a stake in all countries' reputations - the strategy demonstrates how reputation being well-preserved, especially from other countries' point of view. The media spotlight globally is at all countries affected by COVID-19; this could be mirroring how the country's reputation and ability to compete with other countries in dealing with COVID-19. The research method used in this research is a content analysis of the media from April to May 2020. This research aims to see how Indonesia's image is framed in foreign media and to see how the world acknowledges Indonesia's reputation. The Indonesian identity from people's perception abroad becomes the Indonesian reputation benchmark through global mass media writings. The results show Indonesia's low image and reputation, beginning with the weak Indonesian government's public statements, which resulted in an unfavorable perception formed from the news in the following months.
\end{abstract}

Keywords: Indonesia representation; crisis; handling COVID-19; reputation; foreign media

Korespondensi: Dr. Susanne Dida, MM. Universitas Padjadjaran Jln. Raya Bandung-Sumedang KM. 21, Jawa Barat 45363.Email: susanne.dida@unpad.ac.id 
PENDAHULUAN

Corona Virus Disease 2019 (COVID-19) merupakan sebuah penyakit yang berkembang di awal tahun 2020. Ditemukan pertama kali di daerah Wuhan Cina, yang kemudian berkembang secara cepat di seluruh dunia. Virus ini awalnya ditemukan pada Desember 2019, di mana para penderitanya memiliki gejala penyakit mirip pneumonia, yang kemudian dicurigai sebagai virus SARS atau MERS, tetapi kemudian hasil penelitian para ahli virologi Cina mengungkapkan bahwa virus yang berkembang merupakan virus jenis baru, yang diyakini merupakan virus yang menyebar dari sejenis hewan. Di awal Januari 2020 Otoritas Kesehatan Wuhan mengumumkan adanya kematian yang diakibatkan dari virus ini.

Tidak berapa lama dari pengumuman tersebut, pemerintah Thailand melaporkan adanya kasus infeksi di negaranya yang merupakan warga negara Cina yang baru tiba dari Wuhan. Tidak lama berselang pemerintah Jepang pun melaporkan hal yang sama terjadi di negaranya, dan setelah itu negara-negara lain di benua Amerika dan Eropa juga melaporkan hal yang sama. Total terdapat 121 negara di dunia yang melaporkan negaranya terkena infeksi virus ini. Termasuk di dalamnya adalah Indonesia.
Indonesia melaporkan adanya warga negaranya yang terinfeksi setelah adanya laporan seorang warga Depok yang menderita penyakit dicurigai typhus di sebuah rumah sakit yang ternyata disinyalir sebagai COVID-19, dan didapat setelah yang bersangkutan menerima tamu seorang warga negara Jepang di sebuah pertemuan. Setelah itu bermunculan berbagai cluster baru yang melaporkan adanya warga terinfeksi virus ini di wilayah-wilayah lain. Banyaknya laporan mengenai warga yang terinfeksi virus ini ternyata tidak membuat pemerintah secara cepat menangani pembatasan pergerakan, jika di Wuhan, sebagai pusat penyebaran virus pertama kali, pemerintah Cina langsung melakukan 'lockdown' atau karantina wilayah, diikuti oleh negara-negara lain yang mendapati warganya yang terinfeksi virus tersebut, di Indonesia pemerintah tidak dengan segera melakukan itu, padahal World Health Organization (WHO) sudah menyatakan penyakit yang disebabkan oleh virus Corona sebagai sebuah pandemi yang berefek global.

Pemerintah menyatakan pembatasan pergerakan masyarakat antar wilayah, setelah melihat perkembangan warga yang terinfeksi semakin bertambah setiap harinya dengan menetapkan Kedaruratan Kesehatan Masyarakat Corona Virus Disease 2019 (COVID-19) di Indonesia, selain itu Presiden melalui Keputusan Presiden nomor 12 tahun 2020 tentang Penetapan 
Bencana Non Alam Penyebaran Corona Virus Disease 2019 (COVID-19) menetapkan penyakit ini sebagai Bencana Nasional. Kedua ketetapan itu diharapkan dapat menjadi dasar langkah-langkah kebijakan pemerintah pusat maupun daerah selanjutnya dalam menangani penyebaran COVID-19 ini.

Penetapan Status Kedaruratan Kesehatan Masyarakat dan Penetapan Bencana NonAlam dengan menetapkan Virus Corona sebagai bencana nasional ternyata dianggap terlambat oleh beberapa pihak. Sifat virus yang berkembang sangat cepat ditambah dengan belum ditemukannya vaksin bagi penyakit ini membuat penyebaran virus ini sudah terlanjur melewati batas daerah. Ketakutan akan terguncangnya ekonomi ditambah dengan ketakutan akan timbulnya kepanikan di tengah masyarakat ibarat buah simalakama yang harus ditelan oleh pemerintah dan pada imbasnya oleh seluruh masyarakat Indonesia. Semua negara yang terkena dampak virus ini sepakat bahwa pandemi ini merupakan sebuah krisis yang harus ditangani oleh negara, dan hampir semua negara meyakini bahwa krisis ini akan menjadi perhatian seluruh dunia, karena hampir seluruh negara di dunia merasakan dampak dari penyebaran virus yang mengancam jiwa manusia, sementara hak asasi manusia menjadi hal utama yang menjadi fokus utama yaitu hak untuk hidup, yang seharusnya dijamin oleh negara. Keterlambatan ini terlihat dari baru ditetapkannya Peraturan Pemerintah Nomor 20 tahun 2020 pada tanggal 31 Maret 2020 tentang Pembatasan Sosial Berskala Besar di mana detail mengenai teknis pelaksanaannya diatur melalui Peraturan Menteri Kesehatan RI nomor 9 tahun 2020 tentang Pedoman Pembatasan Sosial Berskala Besar Dalam Rangka Percepatan Penanganan Corona Virus Disease 2019 (COVID-19), sementara virus sudah menyebar kemana-mana.

Pada pelaksanaannya PSBB tidak diberlakukan sama di Indonesia. Pemerintah melihat pada keadaan masing-masing daerah sebelum kemudian Menteri Kesehatan menetapkan status PSBB di daerah tersebut sesuai dengan peraturan dan undang-undang yang berlaku. Dalam Peraturan Pemerintah Nomor 21 Tahun 2020 tersebut dijelaskan bahwa PSBB meliputi sekolah dan kantor atau tempat kerja yang diliburkan, kegiatan keagamaan yang dibatasi, demikian jugan fasilitas umum yang juga dibatasi kegiatannya. Presiden menyatakan bahwa penetapan status PSBB di suatu daerah mengacu pada berbagai pertimbangan, yaitu jumlah kasus yang terjadi, jumlah kematian baik yang terjadi di kabupaten atau kota maupun di tingkat provinsi. Pertimbangan epidemiologi, besarnya ancaman, dukungan sumber daya, pertimbangan ekonomi, sosial, budaya, dan keamanan juga menjadi pertimbangan lain 
untyuk diperhatikan dalam menetapkan status sebuah daerah (Kemensetneg, 2020)

Pembatasan Sosial Berskala Besar atau PSBB merupakan sebuah bukti keengganan pemerintah pusat dalam memutuskan karantina wilayah sebagai sebuah kebijakan dalam memutus mata rantai penyebaran virus. Beberapa pengamat menyatakan keengganan tersebut disebabkan karena efek yang harus dipenuhi oleh pemerintah jika memutuskan menggunakan karantina wilayah sebagai sebuah keputusan. Karena seperti yang disebutkan dalam UU Nomor 6 Tahun 2018 tentang Kekarantinaan Kesehatan, disebutkan Karantina Wilayah adalah pembatasan penduduk dalam satu wilayah termasuk wilayah pintu pasuk beserta isinya yang diduga terinfeksi penyakit dan/atau terkontaminasi sedemikian rupa untuk mencegah kemungkinan penyebaran penyakit atau kontaminasi dan dalam hal ini pemerintah berkewajiban memenuhi hak setiap warga negaranya dalam mendapatkan pelayanan kesehatan dasar sesuai kebutuhan medis, kebutuhan pangan dan kebutuhan sehari-hari selama karantina (setkab.go.id, 2018). Hal itu dilakukan oleh semua negara yang memutuskan untuk me-'lockdown' negaranya, tetapi Indonesia memilih PSBB karena PSBB hanya membatasi pergerakan yang paling sedikit meliputi penghentian aktivitas sekolah dan tempat kerja, kegiatan ibdah keagamaan yang dilakukan di tempat umum dan mengumpulkan banyak orang yang dibatasi, juga penutupan fasilitas umum. Ternyata Pembatasan Sosial Berskala Besar (PSBB) di Indonesia pun hanya berlaku sesaat, karena Pemerintah RI mulai memetakan scenario pelonggaran PSBB yang sudah berlangsung hampir tiga bulan sejak Virus Corona ini terdeteksi di Indonesia. Bahkan Presiden menyatakan bahwa Indonesia akan memasuki fase tatanan kehidupan baru yang disebut dengan The New Normal dalam mengatasi pandemi Virus Corona yang dianggapnya tidak juga berakhir.

Selain PSBB yang tidak tegas, pemerintah Indonesia pun membuat kebijakan-kebijakan yang tidak sejalan dengan keadaan pandemi, dimana di tengah negara-negara di dunia menghentikan pariwisata dan mendatangkan turis, Presiden menyatakan memiliki rencana untuk membangkitkan kembali pariwisata di Indonesia dengan memberikan potongan harga sebesar 30 persen. Strategi ini disinyalir diturunkan karena melihat melemahnya sektor periwisata yang disebabkan oleh pandemic yang belum berakhir (Prasetia, 2020). Selain kebijakan membuka pariwisata bagi wisatawan asing, pemerintah Indonesia juga ternyata membuat kebijakan dengan mengizinkan warga negara asing dari Cina untuk memasuki wilayah Indonesia. Laporan menunjukkan sebanyak 49 orang WNA asal Cina masuk ke 
Indonesia di Kendari Sulawesi Tenggara yang berasal dari Bandara Soekarno-Hatta dimana bandara tersebut merupakan pintu masuk untuk menuju daerah lain di Indonesia. Kepala Kantor Imigrasi TPI Kelas I Bandara SoekarnoHatta mengatakan bahwa ia menerima ke-49 orang WNA tersebut karena secara perizinan memiliki dokumen yang lengkap, terutama sertifikat yang kesehatan yang menyatakan bebas corona (Wiryono, 2020). Ternyata berita lain mengungkapkan bahwa warga negara asing yang merupakan TKA Cina yang masuk ke Indonesia bukan berjumlah 49 orang tetapi 500 orang. Fakta ini diungkapkan Anggota Komisi I DPR Sukamta yang menyayangkan pada pemerintah yang memberikan izin pada kedatangan 500 tenaga kerja asing Cina ke Sulawesi Tenggara. Ia menyatakan bahwa pemberian izin kepada warga negara asing untuk bekerja di Indonesia menjadi bukti ketidakpekaan pemerintah Indonesia terhadap keselamatan rakyatnya sendiri, apalagi saat ini Indonesia sedang dalam masa penanganan wabah virus Corona (Cahyani, 2020).

Kebijakan pemerintah yang tidak sejalan dengan ketegasan dalam kepatuhan protocol kesehatan sebagai dasar penanganan COVID-19 ini tidak berhenti sampai disana, karena berbagai ketidaktegasan pemerintah dalam menangani pandemi ini memunculkan kekecewaan para tenaga medis sebagai garda terdepan penanganan COVID-19 yang melihat seolah-olah masyarakat tidak memperdulikan adanya pandemic Corona. Keprihatinan ini menyebabkan munculnya Gerakan digital \#indonesiaterserah yang bertebaran di laman sosial media. Topik atau tagar itu sendiri menggema setelah ditemukan kerumunan yang terjadi di restoran cepat saji Mc Donald yang terletak di Sarinah Jakarta juga adanya keramaian sehingga menimbulkan kerumunan di Bandara Soekarno Hatta (Aida, 2020). Penggunaan tagar Indonesia Terserah ini bahkan viral sampai menjadi pergunjingan di media massa Internasional, tidak kurang media Malaysia, Inggris, Australia memberitakan hal ini, yang tentu akan membuat nama baik negara ini tercoreng, dimana di tengah setiap negara berlomba untuk mengatasi pandemic ini, Indonesia seolah-olah tidak merasa perlu menangani dengan baik.

Penelitian mengungkapkan bahwa di beberapa negara dunia, pandemi ini memaksa para pengambil kebijakan berkreasi dalam penyusunan pesan yang digunakan untuk menggugah masyarakatnya mengikuti protocol kesehatan. Banyak pemerintah bersama dengan tim kreatifnya telah membuat pesan iklan untuk mendorong kesadaran publik. Salah satu contohnya adalah Pemerintah Australia yang mengadopsi logo 'Help stop spread and stay healthy', sementara Pemerintah Inggris 
membuat kampanye dengan slogan, 'Stay home. Protect the NHS. Save lives.' Dalam gambar logonya, slogan tersebut diberikan pembatas warna merah untuk menunjukkan betapa pentingnya pesan tersebut, dan kemudian diubah menjadi 'Stay Alert. Control the Virus. Saves lives.' Dengan warna pembatas slogan diubah menjadi hijau (Mogaji, 2020).

Hasil penelitian yang dilakukan oleh Place Brand Observer mengungkapkan bahwa Korea Selatan dan Jepang adalah dua negara yang dianggap mampu mengelola krisis Corona dengan baik, dan hasil pengelolaan krisis yang baik itu mendapatkan efek global dimana kedua negara tersebut dipandang sebagai negara yang berkinerja baik, sehingga memperoleh reputasi positif dalam penanganan Virus Corona. Tidak seperti negara-negara lain yang dianggap berkinerja buruk, dianggap tidak mampu menangani krisis dengan baik sehingga diprediksi akan menghadapi periode pemulihan akan virus ini lebih lama dari seharusnya. Menurut riset tersebut, negara-negara yang mampu menangani krisis global ini akan memberikan bantuan kepada negara lain dengan cara memberikan contoh cara penanganan, akan keluar sebagai negara yang mendapatkan reputasi baik secara global (Florian, 2020). Bloom Consulting bahkan menyampaikan hasil penelitiannyabahwapandemiglobalinimemiliki dampak besar pada reputasi kerja institusi- institusi yang ada di dunia, dari Organisasi Kesehatan Dunia sendiri, hingga pemerintah nasional dan regional dan bahkan sektor swasta, karena dalam beberapa bulan terakhir, pers internasional secara aktif membandingkan cara negara-negara menangani pandemi COVID-19, dari perkembangan penyakit hingga respon publik, atau bahkan perilaku warga. Krisis ini telah menguji negara-negara di dunia dengan menjadikan mereka pusat opini publik dunia melalui pemberitaan yang disampaikan oleh media-media (Consulting, 2020).

Fenomena-fenomena yang ditunjukkan di awal memperlihatkan keadaan yang bisa diteliti sehingga tujuan penelitian ini adalah memaparkan bagaimana representasi Indonesia di mata dunia pada penanganan COVID-19, yang terlihat pada pemberitaan dan informasi yang beredar di dunia. Dengan pembatasan masalah melihat pada bagaimana identitas indonesia dibangun dan bagaimana persepsi warga negara di luar Indonesia melihat penanganan COVID-19.

\section{METODE PENELITIAN}

Penelitian ini menggunakan metode penelitian deskriptif yang melibatkan pengembangan kerangka pengkodean dan pengkodean kualitatif (Snelson, 2016). Analisis penelitian deskriptif mengenai isi media sendiri 
merupakan metode penelitian yang mencoba membahas secara mendalam isi suatu informasi yang tertulis atau tercetak dalam media massa meskipun dalam hal ini bukan media massa konvensional tetapi media massa yang bersifat online. Analisis kualitatif adalah sebuah metode yang tak mencolok (unobtrusive). Penelitian ini menggunakan analisis deskripsi kualitatif yang berupaya melakukan melihat kembali informasi yang sudah terpublikasi melalui media massa online tersebut, mencoba membuat model (modelling), dan dalam kadar tertentu, mencoba mengkaitkan dengan keadaan sebenarnya terutama melihat dari persepsi atau tanggapan penulis pada keadaan yang terjadi.

Dengan metode penelitian deskriptif, peneliti akan mengolah data dari bahan yang tidak terstruktur sehingga memiliki keleluasaan dalam memanfaatkan data dan juga memiliki kebebasan dalam mengolah data dengan memilih beberapa informasi yang tersedia. Analisis deskriptif sangat peka pada konteks sehingga dapat memproses bentuk-bentuk simbolik dan dapat menghadapi sejumlah besar data.

Metode penelitian deskriptif memiliki tiga syarat yaitu: obyektivitas, generalitas dan sistematis. Obyektivitas adalah penggunaan prosedur serta aturan ilmiah, generalitas adalah relevansi teoritis dari setiap penemuan hasil penelitian, serta sistematis yaitu sebuah proses yang teratur dalam pengkategorisasian data (Kriyantono, 2014).

Data penelitian ini menggunakan tulisantulisan, gambar-gambar, berita-berita yang muncul di media massa maupun media sosial pada bulan April sampai dengan Mei 2020, dengan asumsi pada bulan-bulan tersebut merupakan awal penetapan pengumunan krisis COVID-19 dan penangananya. Media yang menjadi sorotan adalah Reuters, Aljazeera, dan The Star, dengan dasar media yang mewakili di Eropa, Timur Tengah dan Asia.

\section{HASIL DAN PEMBAHASAN}

Penelitian ini merupakan penelitian yang berupaya untuk melihat image sebuah negara di pemberitaan asing. Upaya pemberian image pada sebuah negara merupakan sesuatu yang baru, karena selama ini brand selalu identik dengan sebuah produk, dan brand untuk sebuah tempat biasanya lebih ditujukan kepada tempat yang menjadi destinasi pariwisata. Konsep nation brand dapat dikatakan sebagai tahap awal. Hal ini antara lain karena place branding dan sub-bidangnya (nation branding) dianggap minoritas dalam setiap disiplin ilmu yang terlibat dan bidang studi yang berinteraksi dalam pengertiannya. Sebagai gagasan awal dan minoritas dalam bidang dan disiplin terkait, maka dirasa tepat untuk melakukan penelitian teoritis untuk memperkaya gagasan tersebut 
(Handayani \& Rashid, 2013).

Nation brand juga dikaitkan dengan identitas nasional. Ini digunakan sebagai identitas merek nasional pada tahap awal memperlakukan suatu bangsa sebagai brand. Nation brand merupakan hasil dari sebuah proses nation branding. Jika merunut pada pengertian brand secara konvensional national brand adalah jumlah total dari semua persepsi tentang sebuah negara di benak para pemangku kepentingan di tingkat internasional yang mengandung beberapa elemen yaitu: warga negaranya, destinasi wisata, seni dan budaya, sejarah negara itu, kuliner, mode, selebritis, merk sebuah produk lokal, dll. Sebuah negara sebenarnya sudah memiliki brand yang melekat di benak warga negaranya ataupun warga negara di luar negaranya, baik dengan upaya maupun tanda upaya sadar dalam proses nation branding, karena setiap negara memiliki image yang sudah terbentuk di audiens internasionalnya, baik itu image yang kuat atau lemah, image yang jelas atau tidak jelas (Fan, 2006). Fan menjelaskan bahwa untuk memahami nation brand, dibutuhkan beberapa level, level pertama, level yang paling mudah, nation brand diinterpretasikan sebagai sebuah symbol visual, slogan, atau strapline. Ia diinterpretasikan sebagai sebuah brand termudah untuk dikomunikasikan, dalam hal ini nation brand bisa dilihat pada penggunaan bendera tiap negara. Pada level kedua, nation brand diposisikan sebagai brand yang memayungi banyak sektor yang mengandung brand di bawahnya, seperti pariwisata atau ekspor (Dinnie, 2008). Pada level ketiga, nation brand lebih pada image, reputasi, dan positioning, mirip dengan proses yang terjadi dalam corporate branding (Gilmore, 2002; Teslik, 2007). Di level keempat, tujuan nation branding adalah untuk membangun dan mempertahankan nation competitiveness (Anholt, 2007). Level berikutnya, nation branding membantu kekuatan suatu negara (Fan, 2006), dan di level terakhir nation branding berhubungan dengan pembentukan national identity (Fan, 2006).

Pandemi COVID-19 sendiri telah menjadi sebuah krisis yang menjadi tolak ukur bagaimana negara-negara di dunia dinilai dalam menangani crisis pandemi global ini. Hasil penelitian menunjukkan bahwa negara dengan kinerja terburuk mendapat perhatian lebih banyak daripada negara dengan manajemen krisis yang lebih baik. Artinya, persepsi negatif berdampak lebih besar daripada persepsi positif. Korea Selatan, Jerman, dan Singapura adalah negaranegara yang memperkuat reputasi positif mereka berkat manajemen krisis yang baik, sedangkan AS, Italia, dan Spanyol memiliki dampak negatif yang lebih besar pada brand negara mereka, dianggap sebagai pengelola 
krisis pandemi terburuk (Consulting, 2020).

Indonesia sebagai negara yang juga terkena dampak Penyakit yang disebabkan oleh Virus Corona (COVID-19) bisa dipastikan menjadi sorotan negara-negara lain, karena penanganan yang dilakukan setiap negara akan menunjukkan bagaimana negara itu bisa membangun reputasi dan nama baik negaranya di tengah percaturan dunia. Sepertiyang dikatakan oleh SimonAnholt, reputasi suatu negara sangat memengaruhi cara warga negaranya dan warga negara asing di luar negara itu berpikir tentangnya, cara mereka berperilaku terhadapnya, dan cara mereka menanggapi semua yang dibuat atau dilakukan di sana. Reputasi suatu negara akan terlihat di setiap aspek keterlibatan dengan negara lain dan memainkan peran penting dalam kemajuan ekonomi, sosial, politik, dan budaya negara itu (Anholt, 2007).

Krisis yang terjadi membutuhkan sebuah penanganan, karena pengelolaan komunikasi dalam mengatasi krisis menjadi sebuah modal di dalam memperbaiki reputasi negara. Ada dua strategi yang bisa digunakan dalam menangani krisis komunikasi yaitu: (1) mengelola informasi dan (2) mengelola makna. Mengelola informasi melibatkan pengumpulan dan penyebaran informasi terkait krisis. Mengelola makna melibatkan upaya untuk mempengaruhi cara orang memandang krisis dan/atau organisasi yang terlibat dalam krisis (Comb, 2014).
Menilik pada pendapat Comb Indonesia harus memiliki kemampuan mengelola informasi terkait dengan COVID-19 yang terjadi selain itu juga harus mengelola makna agar masyarakat di dalam negeri atau di luar negeri bisa memberikan makna positif pada informasi yang diberikan. Jika krisis sudah sampai pada terancamnya sebuah reputasi, Indonesia harus menggunakan strategi dalam menangani situasi tersebut, strategi respons krisis dapat dibagi menjadi tiga kategori: menginstruksikan informasi, menyesuaikan informasi, dan memperbaiki reputasi (Comb, 2014).

Reputasi sendiri awalnya adalah sebuah konsep yang digunakan untuk sebuah organisasi. Reputasi akan selalu menjadi hal yang sangat penting bagi organisasi, baik perusahaan, pemerintah, atau organisasi nirlaba. Untuk mencapai tujuan mereka, agar tetap kompetitif dan sejahtera, reputasi yang baik membuka jalan organisasi untuk diterima dan disetujui oleh para pemangku kepentingan. Bahkan organisasi yang beroperasi dalam lingkungan yang tidak etis - yang mungkin diciptakan sendiri - perlu mempertahankan reputasi positif jika memungkinkan (Watson \& Kichen, 2010).

Pada bulan April, media Reuters memberitakan bahwa jumlah kematian akibat virus Indonesia meningkat menjadi tertinggi di Asia di luar China. Indonesia melaporkan 13 kematian lebih lanjut dan 113 kasus baru, 
menjadikan jumlah total infeksi menjadi 1.790. Korea Selatan telah melaporkan 169 kematian dan 9.976 infeksi, menurut angka terbaru yang dirilis di sana. Data tersebut muncul di tengah kekhawatiran yang diungkapkan dan para pejabat bahwa pemerintah Presiden Joko Widodo lambat dalam mengambil tindakan yang serupa dengan yang ada di negara lain untuk mengekang penyebaran virus. Indonesia hanya melaporkan kasus pertama virus satu bulan sebelumnya, tetapi ahli epidemiologi mengatakan tingkat pengujian yang relatif rendah menunjukkan jumlah kasus yang tidak sesuai dengan data sesungguhnya di lapangan, sehingga tampaknya banyak kasus yang tidak dilaporkan. Sebuah model dari Center of Mathematical Modeling of Infectious

Diseases di London School of Hygiene and Tropical Medicine menyebutkan jumlah infeksi sebenarnya di Indonesia antara 22.000 dan 37.000. Sebuah model dari Future of Humanity Institute di Universitas Oxford memperkirakan jumlahnya mendekati 80.000 (Jefriando \& Munthe, 2020). Masih di bulan yang sama Reuters menuliskan:

Jump in Jakarta funeral raises fears of unreported coronavirus deaths. From January 2018 to March 2020 there has been a 40 percent surge in burials, as stated by the Department of Parks and Cemeteries of the City of DKI Jakarta and quoted by Reuter, namely 4,400 burials. As many as 971 cases resulting in 90 deaths causing Jakarta to become the epicenter of corona virus infection in Indonesia; or roughly half the country's total for both. Anies Baswedan as governor of Jakarta, and public health experts suspect that the number of infections and deaths in Jakarta has a higher number than reported due to allegedly low testing rates when compared to other countries. A senior health ministry official did not respond to phone calls and messages requesting comment on the funeral statistic. A spokesman for President Joko Widodo did not respond to request for comment. According to the governor's office, health workers and hospital managers in Jakarta have tried to take special precautions by registering as many as 438 bodies they suspect are infected with COVID-19 from March 6 to April 22020. The action taken was to disinfect and wrap the body in plastic, not using a shroud like a body of a Muslim generally. Indonesia is the world's most populous Muslim majority country. Indonesia is combatting the outbreak of novel coronavirus by introducing social distancing policies, but President Joko Widodo has opposed the harsh lockdown measures adopted in many countries including Indonesia's neighbors. Anie Baswedan, who has been known to act in opposition to Jokowi, has imposed tougher measures in Jakarta, where schools are closed as well as shops and businesses to try to contain the spread of the virus from his area. However, the central government has rejected its call to ban buses from Jakarta to other parts of Indonesia in an effort to filter and eliminate the spread of the virus. (Allard, Kapoor, \& Widianto, 2020).

Perseteruan yang muncul dalampenanganan COVID-19 antara gubernur Anies Baswedan dan Presiden Joko Widodo, menghiasi hampir semua laman media internasional. Aljazeera mengambil judul, Indonesia: More than 2,200 died with coronavirus-like symptoms, di dalam beritanya tercantum:

Indonesia is a country with the fourth largest population in the world 
which has the lowest level of testing in this case of corona virus, so it is very difficult to get an accurate picture of the infection that is happening in the country, this was conveyed by several Indonesian epidemiologists.... President Jokowi's activists and political opponents have even accused the government of not being transparent in dealing with this outbreak. The government says it has taken appropriate measures, but Widodo said last month that some information had been withheld from the public to prevent panic (Aljazeera, 2020).

Reuters juga menurunkan berita yang memiliki informasi yang seragam dengan yang disampaikan oleh Aljazeera, tetapi dengan mengambil judul Exclusive: More than 2,200 Indonesians have died with coronavirus symptoms, data shows.

More than 2,200 Indonesians have died with acute symptoms of COVID-19 but were not recorded as victims of the disease, a Reuters review of data from 16 country's 34 provinces showed. The official figure, which puts the national death toll at 765 , was pointed out by three medical experts as likely to be much higher. Indonesia has one of the lowest testing rates in the world and some epidemiologists say that has made it harder to get an accurate picture of the extent of infections in the world's fourth most populous country. The most current data from the 16 provinces shows there were 2,212 deaths of patients under supervision because they have acute coronavirus symptoms. PDP or Patient Under Supervision is an acronym used by the Indonesian Ministry of Health in classifying patients who have no other clinical explanation for their symptoms. Data is collected by provincial health agencies on a daily or weekly basis so that figures emerge from reports of hospitals, clinics and officials overseeing burials. It was obtained by Reuters by checking websites, talking to provincial officials and reviewing World Health Organization (WHO) reports (Allard \& Lamb, 2020) .

Sementara The Star, masih di bulan April mengambil tajuk After denial, Indonesia sees mounting COVID-19 deaths, isi berita yang muncul di Star adalah:

while Indonesia's neighbors scrambled early this year to try to contain the spread of coronavirus, the government of the world's fourth most populous nation insisted that everything was fine. Indonesia's Health Minister, Terawan Agus Putranto, in a speech he delivered told Indonesians not to be afraid of the virus, even though currently tens of thousands of people worldwide have been infected. Instead of focusing on guidelines in developing social distancing strategies or testing strategies for infected people, Putranto has expressed his admiration for Indonesia's 'immunity' and the power of prayer so that there is no infection in the country. Indonesia did not even confirm its first case of the virus until early March... On Monday (April 20), Indonesia has reported the highest number of deaths due to COVID-19 in any Asian country other than China, namely 6760 infections and 590 deaths,.... Bivitri Susanti, a legal and political observer from the Jentera Indonesia Law School, said that Jokowi had been too late in dealing with the spread of the virus, causing confusion among his government ministers in issuing regulations. "Jokowi has been too slow to lead the fight against this pandemic crisis, instead he has shown his weak leadership. "'(TheStar, 2020).

Beberapa cuplikan berita yang muncul di bulan April 2020 menunjukkan kelemahan pemerintahan Indonesia dalam menangani krisis Pandemi ini. Berita-berita asing menyoroti ketidakpedulian pemerintah dalam menghadapi krisis yang dianggap seperti tsunami ini, 
sementara negara-negara lain bahkan negara tetangga Indonesia seperti Malaysia, Singapura, dan Australia langsung dengan sigap menutup pintu negara-negaranya untuk menghadang penyebaran virus yang lebih parah, Indonesia terkesan membiarkan hal tersebut. Dari beberapa pemberitaan yang muncul dan berulang kali muncul adalah kelemahan data yang disampaikan, baik ketidakakuratan yang disebabkan oleh lambatnya pengukuran, maupun tidak transparansinya kementrian kesehatan. Alasan yang dikemukaan Jokowi sebagai presiden dikarenakan tidak menginginkan adanya kepanikan di tengah masyarakat menjadi blunder, yang membuat kehilangan kepercayaan masyarakatnya sendiri. Para ahli epidemiolog yang berasal dari beberapa universitas di Indonesia pun tidak luput dengan kekecewaan pada penanganan awal pandemi ini sehingga mereka merasa perlu untuk menyampaikan pada media melihat ketidakjelasan kebijakan pemerintah pusat. Beberapa kali kata the world's fourth populous country muncul di setiap berita yang diturunkan oleh tiga media asing tersebut seolah ingin menunjukkan bahwa Indonesia adalah negara yang memiliki penduduk terbanyak, tetapi tidak memperhatikan keselamatan warganya, terutama dari penyakit yang disebabkan oleh virus korona ini. Ketiga media ini dengan secara berkala menyebutkan jumlah korban, dibandingkan dengan jumlah penduduk Indonesia.

Di awal bulan Mei, Reuters kembali menurunkan berita yang cukup menohok, dengan mengambil judul Burial numbers in Jakarta indicate coronavirus toll is higher than officially reported.

In April, usage in Jakarta had a record high, on Friday official data showed there could be more deaths from COVID-19 in Jakarta, more than officially recorded. The latest data shows a total of 4,377 burials, of which 4,422 are burials for March, suggesting that in two months 2,500 people had died, more than the average for that period. So that Jakarta has been named the epicenter of the corona virus outbreak in the fourth most populous country in the world. According to the central government, there had been 375 COVID-19 deaths in the capital as of Saturday..... Some people suspected of having died from COVID-19 were not tested, while some people were suspected of having taken the "wrong" way, Yurianto said. He did not elaborate on what the incorrect samples meant. The highest number of burials occurred in March for Jakarta since burial data began to be collected in this decade, almost a third higher than any month in that period. City Governor Anies Baswedan told Reuters at the time: "I'm struggling to find another reason than unreported COVID-19 deaths."(Allard, 2020).

Memasuki bulan Ramadhan, berita-berita media asing menyoroti kebijakan pemerintah pada protocol kesehatan yang disosialisasikan. Seperti yang sudah diketahui bersama bulan Ramadhan merupakan bulan dimana muslim di seluruh dunia melakukan ibadah yang tidak bisa mengikuti protokol kesehatan. Indonesia sebagai negara yang memiliki jumlah warga 


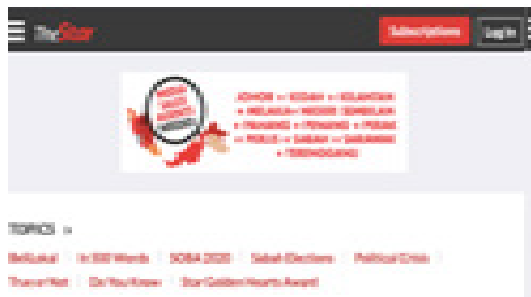

\section{Biggest daily jump in Covid-19 cases in Indonesia}

obgopod

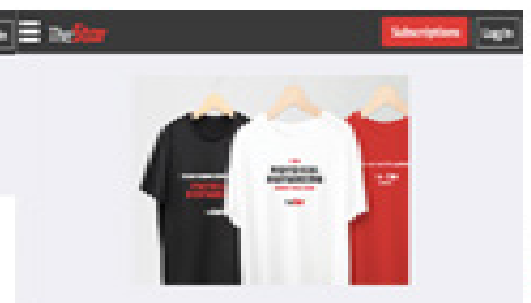

Tha :

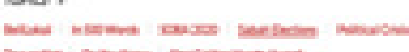

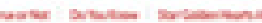

Another 31 people die due to Covid-19 in lndonesia; 292 new coronavirus cases

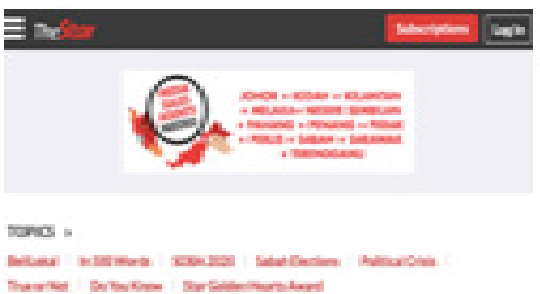

Indonesia records 634 cases and 46 Covid-19 deaths

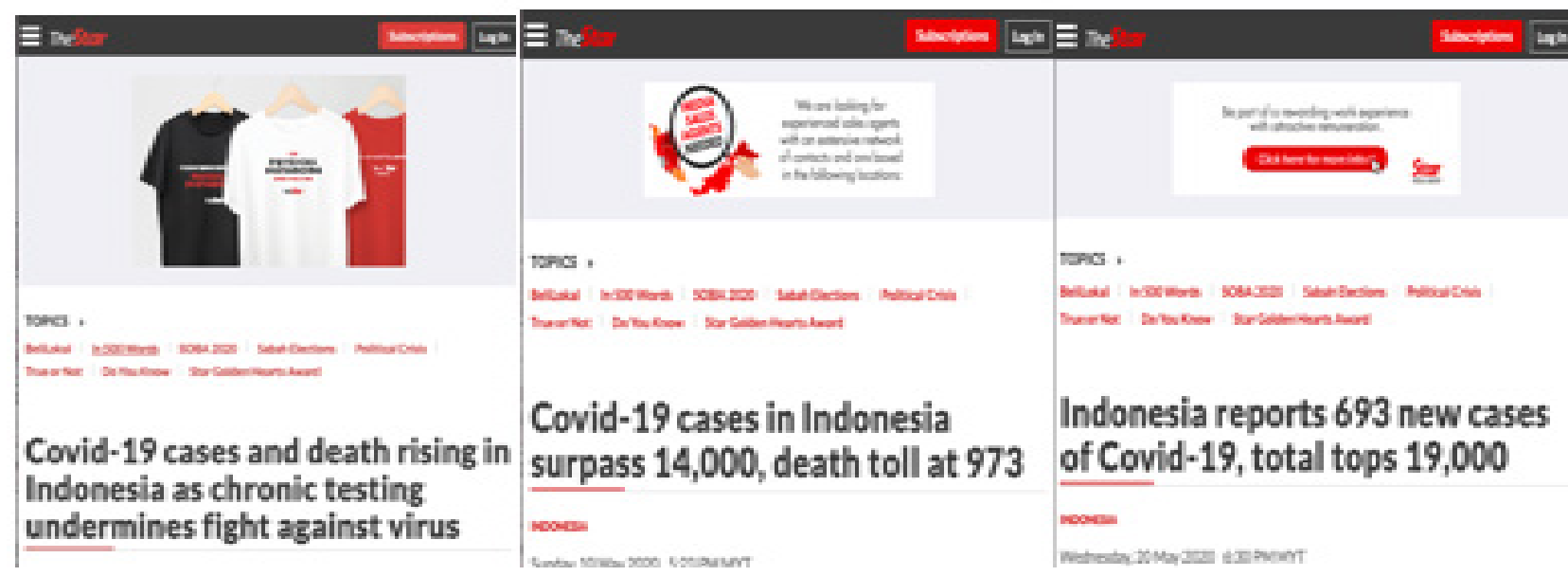

Sumber: TheStar, 2020

Gambar 1 Judul Pemberitaan The Star selama bulan Mei 2020

negara muslim terbanyak, menjadi sorotan di dunia, dimana anjuran untuk tidak berkerumun, dan menjaga jarak sangat sulit untuk dilakukan. The Star menyoroti selama bulan Mei, begitu banyak lonjakan jumlah kasus COVID-19 yang ditemukan di Indonesia, pada tanggal 5 Mei 2020, judul berita yang diangkat Biggest daily jump in COVID-19 cases in Indonesia (TheStar, 2020), dan berita lainnya yang menunjukkan peningkatan jumlah setiap saat.

Selain berita peningkatan jumlah kasus COVID-19, The Star juga menurunkan berita yang berjudul Ramadan rule-breakers:

Indonesians try to beat Aidilfitri exodus ban.

The prohibition tocarryoutEidhomecoming has made many Indonesians try to make fake travel documents and try to smuggle themselves so that they can continue to travel at the end of the month of Ramadan which is an annual holiday for Muslims who are feared could make the COVID-19 (corona virus) case skyrocket in the largest Muslim majority country in the world. Thousands of people take various measures in order to get to their hometowns in time to celebrate at the end of the holy month of fasting, namely Eid al-Fitr or better known as Eid. "It is a critical moment," said Doni Monardo, head of Indonesia's COVID-19 mitigation task force. "I'm afraid people who go to other regions will come back 
infected and all of our efforts will be wasted." The government has imposed a travel ban on land, sea and air, to hinder the movement of people both across regions, regions and across countries, in order to anticipate public health disasters... Netizens who saw the blatant violations of social distancing resulted in the hashtag \#whateverIndonesia became a trending topic in cyberspace, which shows the anger of netizens towards Indonesian society. But even though the hashtag has been circulating in cyberspace, it has not been paid much attention to the people who still play cat and mouse with the police by using various methods, like hiding in a car, under the tarpaulin hanging behind a truck, or even, it is said, in a concrete mixer. (TheStar, 2020).

Pemberitaan The Star di bulan Mei menunjukkan perilaku masyarakat Indonesia yang cenderung tidak mempedulikan larangan pemerintah dalam menjaga protokol kesehatan. Kondisi diperparah karena bertepatan dengan bulan Ramadhan dan Idul Fitri sebagai bulanbulan suci mayoritas Muslim di Indonesia yang sulit untuk melepaskan kebiasan mudik ke kampung halaman. Sorotan The Star sebetulnya sama dengan sorotan media-media lokal di Indonesia yang menunjukkan akan-akalan masyarakat yang berusaha kembali ke kampung halamannya di masa pandemi global ini.

Sementara di bulan Mei 2020, Aljazeera lebih menyoroti persiapan Indonesia untuk membuka kembali perekonomian negara dengan mengusung 'new normal' sebagai senjata utama. Dalam berita yang berjudul, 'New Normal': Indonesian army set to enforce
COVID-19 measures, berisi tentang pesiapan pemerintah dengan memerintahkan pasukan tantara dan polisi mengambil bagian sebagai alat negara.

Indonesia has been preparing to reopen its economy to the outside world after carrying out a lockdown caused by the corona virus, to prepare for that the government ordered the deployment of hundreds of thousands of soldiers and police to enforce regulations on the use of face masks and physical distancing.... The deployment of security forces to serve in the community is ensured to see the public's compliance with the health guidelines set by the government considering that cases of COVID-19 infection continue to increase... Indonesian President Joko Widodo said the measures would help protect people's health and the economy (Aljazeera, 2020).

Reuters pun menyoroti hal yang sama, dengan mengambil judul, Soldiers, police enforce Indonesia's 'new normal' coronavirus restrictions. Isi berita nya kurang lebih sama dengan yang diangkat meskipun ditambah dengan pernyataan Presiden Joko Widodo:

"We want people to be productive while still feeling safe from COVID-19," he said after visiting a mall in Bekasi City. "The military and police will be watching the crowd to make sure people become more disciplined especially in enforcing the adaptation of new habits." (Da Costa, 2020)

Hal-hal yang diangkat selama bulan Mei 2020 oleh berita-berita dimedia asing sebenarnya masih menyoroti angka kasus COVID-19 yang masih belum menunjukkan pengurangan tapi ada perilaku optimis pemerintah untuk segera membuka kembali negara ini dengan alasan 
REUTERS

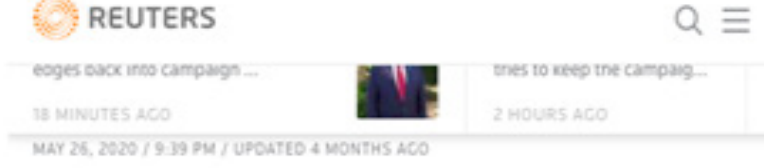

Exclusive: Indonesia, major advocate of hydroxychloroquine, told by WHO to stop using it

By Kate Lamb, Tom Alland

(Reuters) - The World Health Organization has urged Indonesia, one of the world's biggest advocates of two malaria drugs to treat the coronavirus, to suspend such treatment over safety concerns, a source familiar with the advice told Reuters on Tuesday.

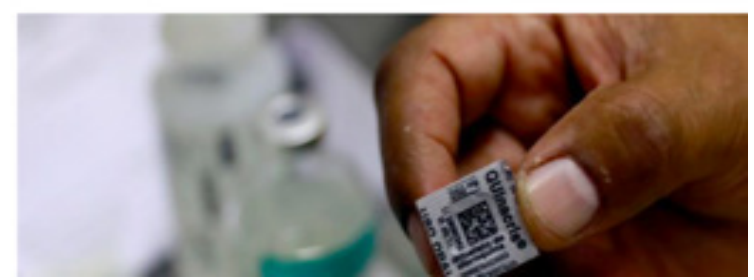

Sumber: Reuters, 2020

\section{Gambar 2 Judul Pemberitaan di Reuters tentang} Anjuran Penghentian Obat Malaria

ekonomi. The Star secara langsung menganggap hal itu sebagai hal yang skeptis. Anggapan mereka tentang ketidakbecusan pemerintah Indonesia ditunjukkan dengan judul berita yang hanya mengangkat angka jumlah pasien COVID-19 yang terus meningkat, sementara Aljazeera dan Reuters memberikan tanda ', pada kata new normal, seolah-olah 'new normal' merupakan padanan kata yang hanya dikenal di Indonesia. Bahkan di waktu yang kurang lebih sama, Reuters mengangkat berita dengan judul, Exclusive: Indonesia, major advocate to hydroxychloroquine, told by WHO to stop using it.
Dalam pemberitaannya dituliskan:

Indonesia, decided while waiting for the official drug to be dispatched to treat COVID-19 patients, ordered the use of drugs that have been used for malaria patients with symptoms from mild to severe. The country, which is the fourth most populous country in the world, has even increased production of malaria drugs since March, granting two dozen licenses to local producers that have produced millions of doses.

Sementara beberapa ahli dari berbagai negara justru melihat berbahayanya penggunaan obat Malaria tersebut bagi penderita COVID-19 karena akan meningkatkan gangguan Jantung.

Stephen Nissen, a cardiologist and chief academic officer of the Miller Family Heart, Vascular \& Thoracic Institute at the Cleveland Clinic, said He was surprised to hear that the Indonesian authorities had recommended the use of this drug widely because he thought the malaria drug would produce side effects resembling a heart attack. "We know this drug produces rare, but very serious and potentially deadly cardiovascular side effects, namely heart rhythm, disturbances. which is very difficult to treat." Jane Quinn, a pharmacology researcher at Charles Sturt University in Australia, said that this anti-malarial drug is indicated to be more dangerous for Indonesians, because of the enzyme profile of the Indonesian population. (Lamb \& Allard, 2020).

Berita itu seolah penegasan bahwa pemerintah Indonesia tidak melakukan riset dengan sungguh-sungguh dalam pencarian obat bagi penderita COVID-19, bahkan WHO pun sampai menegur pemakaian obat tersebut Berita-berita yang diangkat di media- 


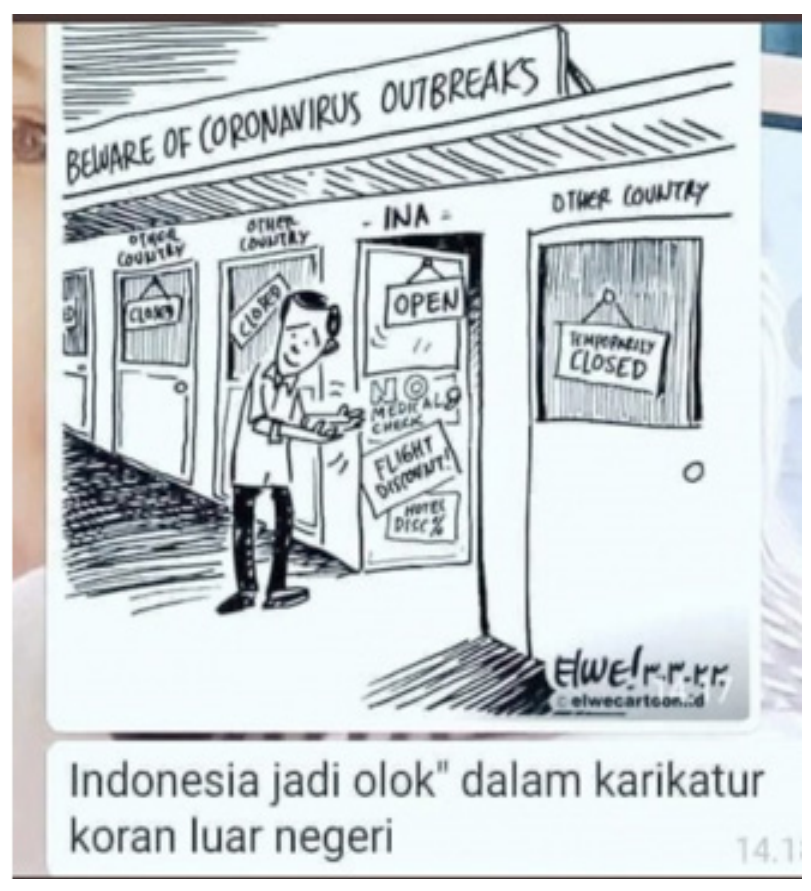

Sumber: Twitter, 2020

Gambar 3 Meme santainya Indonesia hadapi Corona

media asing tentang penanganan COVID-19 di Indonesia diawali dengan ketidakpercayaan negara lain pada pemerintah Indonesia, karena diawali dengan keyakinan bahwa Indonesia tidak akan terkena virus ini. Hal ini menjadi topik sentral di beberapa negara bahkan memunculkan meme di media sosial

Pada bulan Mei 2020, Reuters memberitakan tentang protes yang dikemukaan oleh para tenaga kesehatan melihat kebijakan pemerintah yang seolah setengah hati dalam menangani COVID-19 ini, diawali dengan kerumunan massa yang berkumpul di Sarinah ketika penutupan restaurant cepat saji Mc Donald, kemudian juga banyaknya orang berkumpul di bandara Soekarno Hatta.
Protes ini berawal dari sebuah hashtag yang disebarkan oleh seorang dokter di twitter dengan menggunakan istilah \#indonesiaterserah. Hashtag tersebut diterjemahkan dalam Bahasa Inggris menjadi \#IndonesiaWhatever. Reuter mengambil judul dalam pemberitaannya

\#IndonesiaWhatever: Indonesians vent online over virus response. A flood of criticism of the Indonesian government's response to the coronavirus pandemic and the behavior of many Indonesian has appeared on social media under a hashtag that translates as \#IndoensiaWhatever. The post originated from the status post of a doctor and social media influencer, Tirta Mandira Hudhi, who was angry with the loosening of the flight ban which caused a large number of passengers to flood Jakarta's Soekarno Hatta airport making it impossible to restrict social distancing. On his Instagram account, doctor Tirta shows a photo of himself wearing complete personal protective equipment, holding a paper that says "Indonesia? Whatever. Do what you want! ". The post attracted the attention of more than 400,000 followers

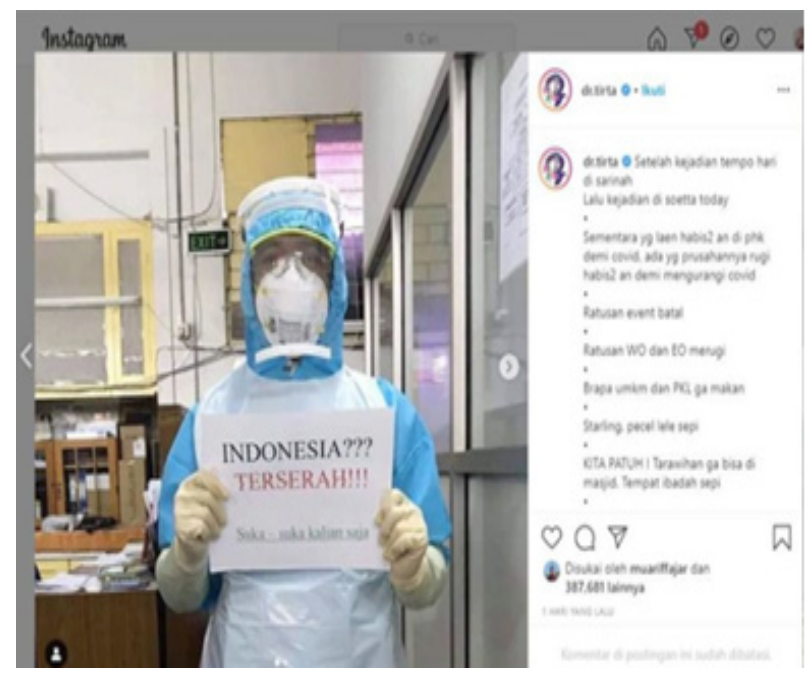

Sumber: Instagram, 2020

Gambar 4 Tangkapan Layar Postingan dr. Tirta \#IndonesiaTerserah 
and expressed likes and the hashtag \#IndonesiaTerserah are among the top trending groups on Instagram and Twitter, and has been shared more than a thousand times. (Da Costa \& Stanley, 2020)

Pemberitaan ini diikuti pula oleh pemberitaan asing lain, The Star dalam halaman pemberitaannya memberikan judul,

Hashtag '\#Indonesia? Terserah!!” takes the country's social media by storm. "\#Indonesia?Terserah!!!" ("\#Indonesia?It is up yo you!!!") is the top trending hashtag on Indonesian social media that shows disappointment at the attitude shown by the Indonesian people who ignore the largescale social restrictions (short for PSBB) that were put in place to limit the spread of COVID-19 in the country. . The hashtag was allegedly started by health workers on May 15, which then attracted the attention of netizens, and then spread on social media, such as Twitter and Instagram.

(TheStar, 2020)

Pemberitaan mengenai meluasnya hashtag

\section{Hashtag '\#Indonesia? Terserah!!' takes the country's social media by storm}

IOCIAL MEDIA

Wednesday, 27 May 2020 10:30 AM MYT
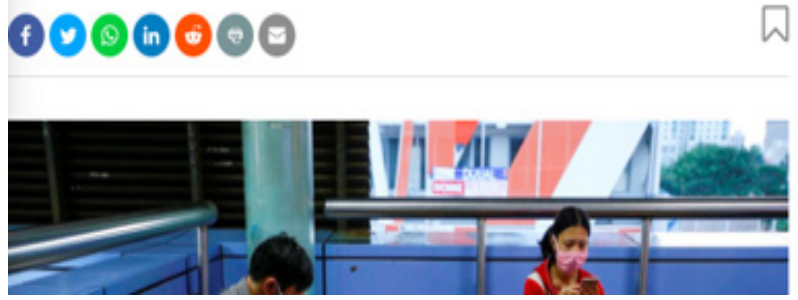

Sumber: TheStar, 2020

Gambar 5 \#IndonesiaTerserah dalam The Star ini pun diliput oleh media-media nasional yang menyampaikan kekhawatiran akan nama baik Indonesia disoroti sebagai negara yang tidak becus dalam menangani pandemi ini, sehingga banyak media lokal yang menjadikan trending topik, ketika pemberitaan ini meluas di media-media luar. Baik Reuters maupun The Star menunjukkan bahwa jumlah penderita COVID-19 masih tinggi jika dibandingkan dengan negara lain. The Star, bahkan pada akhir artikelnya tetap menyertakan jumlah kasus penderita COVID-19 di Indonesia yang belum menunjukkan penurunan.

Ketidakpercayaan itu menjadi berantai pada pemberitaan-pemberitaan selanjutnya yang tidak mempercayai data yang diberikan pemerintah. Hal tersebut dapat menggambarkan bagaimana reputasi Indonesia di mata dunia. Untuk mengukur reputasi ini digunakan pengukuran reputasi yang dikenal dengan Reputation Quotient dari Bronn dan Bronn yang mengatakan elemen-elemen dalam mengukur reputasi bisa dilihat dari lingkungan kerja, daya tarik emosional, performa keuangan, kepeminpinan maupun visi organisasi dan pimpinannya, kepemimpinan dalam lingkungan sosial, produk juga layanan yang diberikan(Bronn \& Broon, 2006). Elemen ini sebenarnya digunakan untuk mengukur reputasi sebuah organisasi tetapi seperti yang dikatakan oleh Passow dkk, bahwa sebuah negara dalam 
menghadapi competitive advantage harus untuk menghindari kepanikan. Daya tarik membangun reputasi negaranya. Mengapa emosi yang ditunjukkan pemerintah pusat demikian? karena negara merupakan sebuah dengan tidak menganggap serius virus ini organisasi layaknya sebuah perusahaan, maka pada awalnya tetapi kemudian mengakui penggunaan elemen-elemen reputasi bisa meskipun tetap dengan 'tidak terlalu digunakan (Passow, Fehlman, \& Grahlow, mengakui' adanya virus ini dalam mengatasi 2005)

Menilik dari pemberitaan yang muncul tentang Indonesia jika menggunakan elemenelemen tersebut: lingkungan kerja bisa dilihat dari negara Indonesia secara keseluruhan COVID-19, menunjukkan ketidakberdayaan menghadapi krisis. Kepemimpinan yang lemah dan cenderung lambat dalam mengambil keputusan juga ditunjukkan dari lambatnya berbagai kebijakan dan ketidaktegasan dalam menunjukkan kesimpangsiuran informasi. memberlakukan protokol kesehatan bagi Kesimpang siuran tersebut menimbulkan penanganan COVID-19. Performa ekonomi kegelisahan aparat, pemerintah daerah, dan yang kurang baik terlihat dari keengganan dalam masyarakat yang tidak diberikan informasi menggunakan kebijakan karantina wilayah secara gamblang, meskipun dengan maksud dengan alasan faktor ekonomi, kelambatan

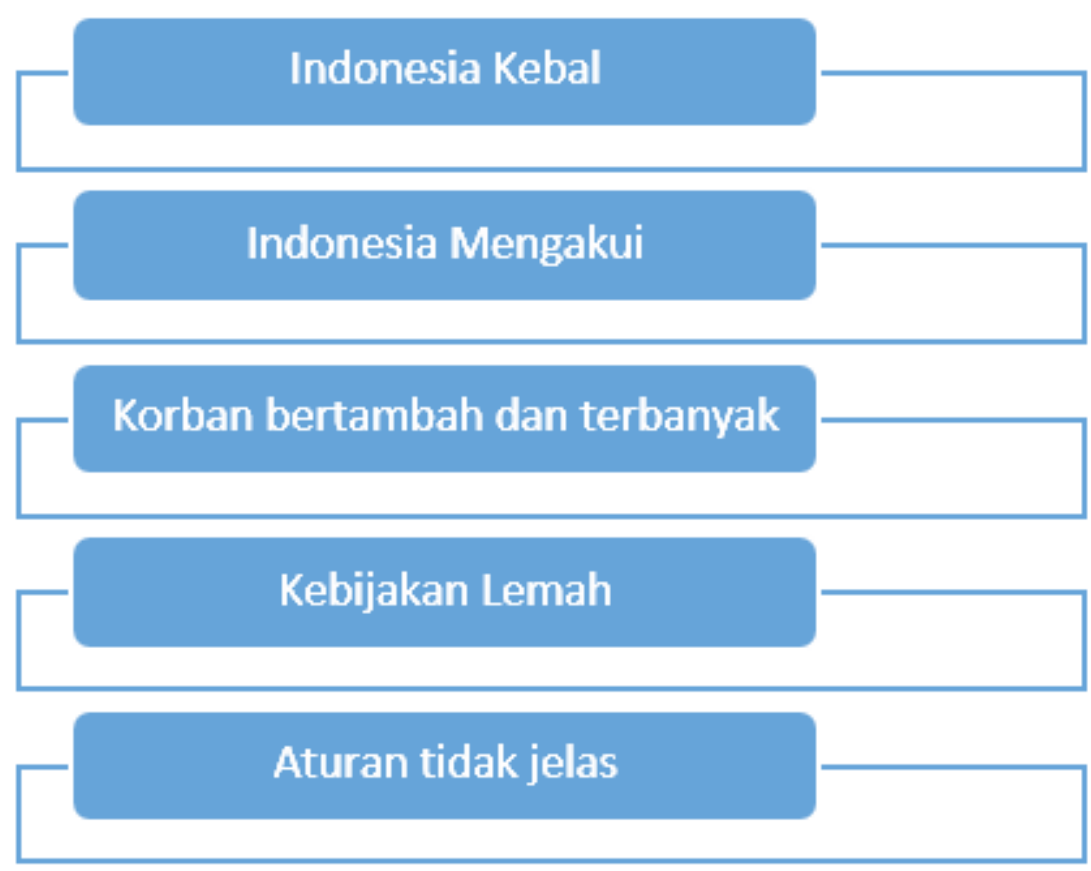

Sumber: Hasil Penelitian, 2020

Gambar 6 Identitas Indonesia melalui Pemberitaan Media Asing 
dalam melakukan test secara massif dan terlalu cepat membuka diri dalam rangka mempercepat laju ekonomi. Tanggung jawab sosial yang kurang dengan tidak terlalu melakukan riset yang diperlukan untuk kepentingan masyarakat banyak, sehingga hanya menghasilkan obat yang tidak bisa dipertanggungjawabkan. Pelayanan pemerintah pada warga negara yang kurang terutama dalam penanganan kesehatan sebagai hak warga negara membuat jumlah korban yang semakin meningkat setiap bulan.

Jika digambarkan bagaimana Identitas Indonesia dibangun melalui pemberitaan di bulan April Mei 2020 bisa terlihat pada gambar 6.

Sementara persepsi warga di luar Indonesia melihat Indonesia jika menilik pada pemberitaan media asing di bulan April-Mei 2020, pada gambar 7
Pandemi COVID-19 ini merupakan krisis yang terjadi di seluruh negara di dunia. Semua negara berlomba untuk menunjukkan penanganan di dalam negerinya untuk menjaga kepercayaan negara lain. Tujuan tindakan tersebut adalah agar jika pandemi ini telah berakhir maka kehidupan percaturan dunia akan berlangsung kembali. Seperti yang dikatakan oleh Bloom bahwa normalnya, semua krisis mempengaruhi persepsi negara untuk periode waktu tertentu. Nantinya, persepsinya akan kembali seperti sebelum krisis. Persepsi yang terpengaruh selama periode singkat tidak mendukung perubahan citra yang bertahan lama (Consulting, 2020).

Citra suatu negara dibangun dari waktu ke waktu melalui persepsi. Persepsi ini berpusat di sekitar Pemerintahan Publik, Identitas, dan Budaya serta Tanah dan Sejarahnya. Pada 
akhirnya, citra ini akan membangun gagasan sentral yang akan membangkitkan emosi negara.

\section{SIMPULAN}

Krisis ini bukan sesuatu yang diinginkan oleh negara manapun, tetapi sebagaimana krisis harus dihadapi, dan dilalui dengan sebuah strategi. Strategi menghadapi krisis sangatlah banyak, tetapi salah satunya adalah dengan menggunakan media. Media, baik media yang ada di dalam negeri maupun media yang berlokasi di luar negeri, merupakan alat yang bisa dimanfaatkan untuk jendela bagi sebuah negara, baik untuk mengamati negara lain, maupun untuk menunjukkan diri pada negara lain.

Media merupakan alat untuk membangun brand sebuah negara baik secara sengaja ataupun atas karena adanya sebuah fenomena yang dianggap memiliki nilai berita. COVID-19 merupakan fenomena yang memiliki nilai berita tinggi karena menjadi perhatian seluruh warga dunia, dan apapun yang diberitakan akan menjadi santapan khalayak sehingga menjadi jendela dalam melihat apa yang terjadi di sebuah negara. Baik tidaknya reputasi sebuah negara akan terbaca dari pemberitaan media yang disampaikan secara luas.

Dari media pula identitas sebuah bangsa akan terbangun, bahkan melalui media pula persepsi warga negara lain pada negara ini akan terlihat. Setiap kalimat dan simbolyang dibangun dalam pemberitaan akan menunjukkan wacana yang terbangun dari pemberitaan tersebut, dan sudah seharusnya setiap pengelola krisis membaca dan menyadari wacana tersebut akan membangun brand sebuah negara terbangun.

Reputasi yang dibangun pada saat menangani sebuah krisis seperti pandemi global ini menjadi pertaruhan negara tersebut untuk mendapatkan nama baik untuk bisa ditempatkan di antara negara-negara di dunia, terutama sebagai upaya untuk menghadapi kehidupan pasca krisis. Negara harus kembali dalam keadaan normal, dan berkompetisi kembali secara global untuk mulai menghidupi kembali negara dan rakyatnya.

Saran yang bisa diberikan jika melihat hasil penelitian ini adalah diperlukan kehati-hatian dalam memberikan keterangan dan pernyataan publik karena, informasi yang sudah menjadi milik public akan dipersepsi sesuai pengalaman publik pada informasi sebelumnya.

\section{DAFTAR PUSTAKA}

Aida, N. R. (2020). Indonesia terserah kebijakan plin plan dan pembiaran negara. Retrieved from https://www.kompas. com/tren/read/2020/05/18/093500665/ indonesia-terserah-kebijakan-plin-plandan-pembiaran-negara-?page $=$ all

Aljazeera. (2020). Indonesia more than 2200 
died with coronavirus like symptoms. Retrieved from https://www.thejakartapost. com/news/2020/04/28/more-than-2200indonesians-have-died-with-coronavirussymptoms-data-shows.html

Allard, T. (2020). Burial numbers in Jakarta indicate coronavirus toll is higher than officially reported. Retrieved from https://www.reuters.com/article/ushealth-coronavirus-indonesia-cases/ burial-numbers-in-jakarta-indicatecoronavirus-toll-is-higher-than-officiallyreported-idUSKBN22D4XI

Allard, T., Kapoor, K., \& Widianto, S. (2020). Exclusive jump in jakarta funerals raises fears of unreported coronavirus deaths. Retrieved from https://www.reuters.com/ article/us-health-coronavirus-indonesiafunerals/exclusive-jump-in-jakartafunerals-raises-fears-of-unreportedcoronavirus-deaths-idUSKBN21L2XU

Allard, T., \& Lamb, K. (2020). Exclusive: More than 2,200 Indonesians have died with coronavirus symptoms, data shows. Retrieved from https://www.reuters.com/ article/us-health-coronavirus-indonesiacasualti/exclusive-more-than-2200indonesians-have-died-with-coronavirussymptoms-shows-idUSKCN22A04N

Anholt, S. (2007). Competitive identity. New York: palgrave macmillan.

Bronn, C., \& P, B. (2006). Reputation and organizational efficiency: a data envelopment analysis study. Corporate Reputation Review, 45-58. Retrieved from https://link.springer.com/article/10.1057/ palgrave.crr.1540238

Cahyani, D. R. (2020). tka-cina-masuk-risaat-corona-dpr-pemerintah-tak-peka. Retrieved from tempo.cp website: tka-cinamasuk-ri-saat-corona-dpr-pemerintah-tak- peka.

Comb, W. T. (2014). The value of communication during a crisis: insight from strategic communication research. Business Horizon, 1-8. https://doi.org/https://doi. org/10.1016/j.bushor.2014.10.003

Consulting, B. (2020). What nation brands must do to tackle COVID-19. Bloom Consulting Journal. Retrieved from https:// www.bloom-consulting.com/journal/ what-nation-brands-must-do-to-tackleCOVID-19/

Da Costa, A. B. (2020). soldiers police enforce indonesias new normal coronavirus restrictions. Retrieved from https://www. reuters.com/article/us-health-coronavirusindonesia/soldiers-police-enforceindonesias-new-normal-coronavirusrestrictions-idUSKBN2320IJ

Da Costa, A. B., \& Stanley, W. (2020). \#IndonesiaWhatever: Indonesians vent online over virus response. Retrieved from https://www.reuters.com/article/us-healthcoronavirus-indonesia/indonesiawhateverindonesians-vent-online-over-virusresponse-idUSKBN22U194

Dinnie, K. (2008). Nation branding. Amsterdam: Elsevier.

Fan, Y. (2006). Academic papers branding the nation: what is being branded? Journal of Vacation Marketing, 5-14. $\quad$ https://doi.org/https://doi. org/10.1177\%2F1356766706056633

Florian. (2020). What corona pandemic means for place branding. Retrieved from https:// placebrandobserver.com/what-coronapandemic-means-for-place-branding/

Handayani, B., \& Rashid, B. (2013). Conceptulisation of nation brand image. IJMS, 165-183.

Jefriando, M., \& Munthe, B. C. (2020). 
Indonesia virus death toll rises to highest in asia outside china. Retrieved from https://www.reuters.com/article/us-healthcoronavirus-indonesia-jakarta/indonesiavirus-death-toll-rises-to-highest-in-asiaoutside-china-idUSKBN21K0LL

Kemensetneg. (2020). Presiden: Pengambilan Keputusan Terkait PSBB Harus Hatihati. Retrieved from https://www.setneg. go.id/baca/index/presiden_pengambilan_ keputusan_terkait_psbb_harus_hati_ hati\#: :text=Presiden\%3A Pengambilan Keputusan Terkait PSBB Harus Hati-hati,Indonesia \%7C English\&text=Presiden Joko Widodo menjelaskan bahwa,hatian dan tidak terburu-buru.

Kriyantono, R. (2014). Teknik praktis riset komunikasi. Jakarta: Kencana.

Lamb,K.,\&Allard,T.(2020).ExclusiveIndonesia major advocate of hydroxychloroquine told by who to stop using it. Retrieved from https://www.reuters.com/article/ushealth-coronavirus-indonesia-chloroqu/ exclusive-indonesia-major-advocate-ofhydroxychloroquine-told-by-who-to-stopusing-it-idUSKBN23227L

Mogaji, E. (2020). Branding the pandemic: coronavirus, COviD19 or SARS-CoV-2. https://doi.org/https://www.researchgate. net/deref/http $\% 3$ A \% 2F\%2Fdx.doi. org $\% 2$ F $10.2139 \% 2 F s s r n .3607532$

Passow, T., Fehlman, R., \& Grahlow. (2005). Country Reputation - From Management to Measurement. Corporate Reputation Review, 309-326. https:// doi.org/https://www.researchgate. net/deref/http $\% 3 \mathrm{~A} \% 2 \mathrm{~F} \% 2 \mathrm{Fdx}$.doi. org\%2F10.1057\%2Fpalgrave.crr.1540229

Prasetia. (2020). Genjot pariwisata di tengah corona jokowi beri turis diskon. Retrieved from https://news.detik.com/ berita/d-4903193/genjot-pariwisata-ditengah-corona-jokowi-beri-turis-diskon

Snelson, C. L. (2016). Qualitative and mixed method. s social media research: a review of the literature. International Journal of Qualitative Methods, 1-15. DOI: $10.1177 / 1609406915624574$

TheStar. (2020). after-denial-indonesia-seesmounting-COVID-19-deaths.

Watson, T., \& Kichen, P. J. (2010). Strategic marketing management. https://doi. org/https://www.cengage.co.uk/ books/9781844800001/

Wiryono. (2020). WNA China masuk Indonesia ini penjelasan imigrasi bandara-soekarno. Retrievedfromhttps://megapolitan.kompas. com/read/2020/03/19/18255551/49-wnachina-masuk-indonesia-ini-penjelasanimigrasi-bandara-soekarno?page $=$ all 